\title{
Protein supply and requirement of grazing yak in China
}

\author{
B. Xue ${ }^{1,2,3}$, S.-J. Liu' ${ }^{1}$ X.-Q. Zhao ${ }^{2}$, L.H. Hu ${ }^{1}$ and X.G. Han ${ }^{1}$ \\ ${ }^{1}$ Qinghai Academy of Animal Science and Veterinary Medicine \\ Xining 810003, P.R. China \\ ${ }^{2}$ Northwest Institute of Plateau Biology, Chinese Academy of Sciences \\ Xining 810003, P.R. China \\ ${ }^{3}$ Institute of Animal Nutrition, Sichuan Agricultural University \\ Ya'an Sichuan 625014, P.R. China
}

\begin{abstract}
Forage supply of native grassland in Qinghai-Tibet Plateau reaches the greatest point in August and the lowest in the beginning of May. Feed intake of yak reached the greatest point in spring, followed by winter, and the lowest in autumn. Digestible CP (DCP) requirement $(\mathrm{g} / \mathrm{d})$ for maintenance in growing yak is $6.09 \mathrm{~W}^{0.52}$, and that for gain is $\left(1.1548 / \mathrm{DG}+0.0509 \mathrm{~W}^{0.52}\right)^{-1}$. There is a sever shortage of forage and CP supply in winter and spring. Grazing yak should be supplemented with $67.4 \mathrm{~g} / \mathrm{d}$ DCP in the first cold season and $58.4 \mathrm{~g} / \mathrm{d}$ DCP in the second cold season for normal growth.
\end{abstract}

KEY WORDS: grassland, protein requirement, yak

\section{INTRODUCTION}

The native rangelands of Qinghai-Tibet Plateau are characterized by low temperature and high altitude. Frigid weather conditions shorten the growth period of vegetation to about 100 to $150 \mathrm{~d}$ and prolong the dormant period to almost 7 month. During the vegetative growth season from May to September, there is an increased forage supply, which is expected to increase yak body weight (BW). As the forage supply declines in winter, yak BW declines (Long et al., 1999). Some yaks cannot survive the extended shortage of forage supply. Losses of up to $30 \%$ of the yak population have been reported in extremely cold years (Long et al., 1999). This has resulted in a centuries' old grassland yak production cycle where the yak is

\footnotetext{
${ }^{3}$ Corresponding author: e-mail: xuebai2000@yahoo.com
} 
expected to "satiate in summer, fatten in autumn, become thin in winter and die in spring" on the Qinghai-Tibet Plateau. Existing information documenting seasonal changes in nutrient supply and nutrient needs of yak is limited. The objective of this paper was to elucidate the balance between $\mathrm{CP}$ supply and $\mathrm{CP}$ need of yaks grazing on native grassland in Qinghai-Tibet Plateau in China.

\section{MATERIAL AND METHODS}

\section{Experiment design and treatment}

Forage samples in different grassland type were collected in May, Jul, Aug, Oct, and Dec, 2002. Harvests of plant biomass consisted of clipping vegetation from ten, $1 \mathrm{~m}^{2}$ rectangular quadrats on the native grassland. Edible forages were separated for calculating CP supply.

Thirty five yaks were divided into 7 groups. Yaks in the same group had the same age, from 1- to 7-yr old, with 5 yaks in each group. All the yaks grazed on native grassland. Feed intake was calculated by using AIA as endogenous marker. The experiment consisted of 5 periods correspondingly in Nov 2001, May 2002, July 2002 and Oct 2002.

Eighteen de-sexed male yaks, aged $1.5 \mathrm{yr}$ and weighed $85 \mathrm{~kg}$, were divided randomly into 3 groups (6 in each) for a 90 -d feeding trial. Their average initial $\mathrm{BW}(85 \mathrm{~kg})$ did not differ among the groups $(\mathrm{P}>0.05)$. Each group received a ration with different $\mathrm{CP}$ level. One yak from each group at the beginning of feeding trial and three yaks from each group at the end of feeding trial were slaughtered for comparative slaughter trial. The remaining 6 yaks after feeding trial were fed low $\mathrm{N}(0.1576 \%)$ diet for determining the endogenous urea $\mathrm{N}$ and metabolic faecal $\mathrm{N}$. Nitrogen balance trial was performed during feeding trial.

Forty yaks were allocated at birth to 2 groups, 10 yaks served as supplementation group, the other 30 as control group. Their average initial BW was $11.5 \pm 0.70 \mathrm{~kg}$, which did not differ between the groups $(\mathrm{P}>0.05)$. All yaks grazed on the native grassland, with monthly weighing for 26 consecutive months. Supplementation group were supplemented with $700 \mathrm{~g} / \mathrm{d}$ concentrate in cold season. The first cold season was from Oct 2001 to May 2002, and the second from Oct 2002 to May 2003. Concentrate was composed of, $\%$ : lucerne 40 , wheat bran 37.5 , maize 21 , salt 0.5 , and additive 1 , with CP $12.62 \%$ and $8.74 \mathrm{MJ} / \mathrm{kg} \mathrm{ME}$.

\section{Chemical analysis}

Crude protein in grass, diet, faeces, urine and carcass was determined using Kjeldahl procedure. Dry matter of all the samples was determined by oven-drying at $105^{\circ} \mathrm{C}$ for $20 \mathrm{~h}$. 


\section{Statistical analysis}

Food intake, above-ground biomass of edible forage data were compared across season using the GLM procedure of SAS (1993). Season was the dependent variable. The significance level was 0.05 . Means were separated using the least significant difference.

\section{RESULTS}

Above-ground biomass of edible forage is greater in summer and autumn than in winter and spring in different grasslands (Table 1), and that in spring is only 15 to $44 \%$ of that in summer and autumn.

Table 1. Seasonal dynamic of above-ground biomass of edible forage in different grassland type, $\mathrm{g} / \mathrm{m}^{2}, \mathrm{DM}$ basis

\begin{tabular}{lcccc}
\hline Grassland type & Spring & Summer & Autumn & Winter \\
\hline Mountainous & & & & \\
$\quad$ meadow & $37.8 \pm 2.09^{\mathrm{a}}$ & $72.9 \pm 5.05^{\mathrm{b}}$ & $97.1 \pm 7.00^{\mathrm{c}}$ & $41.6 \pm 3.17^{\mathrm{d}}$ \\
$\quad$ desert & $34.7 \pm 0.88^{\mathrm{a}}$ & $66.9 \pm 2.38^{\mathrm{b}}$ & $79.3 \pm 3.36^{\mathrm{c}}$ & $47.1 \pm 3.63^{\mathrm{d}}$ \\
$\quad$ steppe & $19.6 \pm 1.33^{\mathrm{a}}$ & $38.2 \pm 4.57^{\mathrm{b}}$ & $47.1 \pm 3.58^{\mathrm{c}}$ & $27.2 \pm 3.23^{\mathrm{d}}$ \\
Plain desert & $3.3 \pm 0.08^{\mathrm{a}}$ & $15.6 \pm 0.73^{\mathrm{b}}$ & $21.9 \pm 2.16^{\mathrm{c}}$ & $9.7 \pm 0.10^{\mathrm{d}}$ \\
Alpine meadow & $8.8 \pm 0.43^{\mathrm{a}}$ & $44.4 \pm 4.19^{\mathrm{b}}$ & $40.4 \pm 5.43^{\mathrm{bc}}$ & $37.9 \pm 5.00^{\mathrm{cd}}$ \\
\hline
\end{tabular}

spring: from Feb. to May; summer: May to Jul; autumn: Jul to Oct; winter: Oct to next Feb a,b,c,d means within row with an uncommon superscript are different $(\mathrm{P}<0.05)$

Table 2. Seasonal dynamic of CP supply of native grassland in Sunan County, $\mathrm{g} / \mathrm{m}^{2}$

\begin{tabular}{lcccc}
\hline Grassland type & Spring & Summer & Autumn & Winter \\
\hline Mountainous & & & & \\
$\quad$ meadow & 3.137 & 8.631 & 10.516 & 2.999 \\
desert & 2.006 & 8.035 & 8.358 & 2.520 \\
steppe & 1.303 & 4.622 & 4.875 & 1.746 \\
Plain desert & 0.207 & 2.078 & 2.372 & 0.540 \\
Alpine meadow & 0.531 & 5.537 & 4.323 & 2.259 \\
\hline
\end{tabular}

a,b,c,d means within row with an uncommon superscript are different $(\mathrm{P}<0.05)$

Seasonal dynamic of CP supply of native grassland are summarized in Table 2. CP content of grass in different grassland in spring ranged from 5.33 to $7.21 \%$, and that in summer ranged from 11.45 to $13.32 \%$. For the same grassland type, CP supply in summer and autumn was 8 to 20 times of that in spring, and 4 to 5 times of that in 
winter. Therefore, seasonalCPsupplyofdifferenttypeofgrasslandis quiteimbalance. There is a sever shortage of CP supply in winter and spring, especially in spring. Feed intake of yak (Table 3) reached the greatest point in spring, followed by winter, and the lowest in autumn. In most cases, forage supply of grassland can not meet the feed intake of yak, due to the overstocking.

Table 3. Seasonal dynamic of DM intake of yak grazing on native grassland, $\mathrm{kg} / \mathrm{d}$

\begin{tabular}{lcccccc}
\hline Age, year & 1 & 2 & 3 & 4 & 5 & 6 \\
\hline Spring & $2.9 \pm 0.3^{\mathrm{a}}$ & $5.5 \pm 0.5^{\mathrm{a}}$ & $7.7 \pm 0.5^{\mathrm{a}}$ & $8.6 \pm 0.5^{\mathrm{a}}$ & $9.2 \pm 0.9^{\mathrm{a}}$ & $9.2 \pm 0.6^{\mathrm{a}}$ \\
Summer & $3.3 \pm 0.4^{\mathrm{b}}$ & $4.7 \pm 0.6^{\mathrm{b}}$ & $6.1 \pm 0.5^{\mathrm{b}}$ & $7.6 \pm 0.5^{\mathrm{bc}}$ & $8.0 \pm 0.7^{\mathrm{bc}}$ & $8.4 \pm 0.7^{\mathrm{b}}$ \\
Autumn & $2.4 \pm 0.5^{\mathrm{a}}$ & $3.6 \pm 0.4^{\mathrm{c}}$ & $4.3 \pm 0.4^{\mathrm{c}}$ & $7.2 \pm 0.6^{\mathrm{b}}$ & $7.6 \pm 0.6^{\mathrm{b}}$ & $7.7 \pm 0.8^{\mathrm{c}}$ \\
Winter & $3.7 \pm 0.3^{\mathrm{b}}$ & $5.3 \pm 0.7^{\mathrm{ad}}$ & $6.8 \pm 0.6^{\mathrm{d}}$ & $7.7 \pm 0.6^{\mathrm{cd}}$ & $8.1 \pm 0.7^{\mathrm{cd}}$ & $8.4 \pm 0.8^{\mathrm{bd}}$ \\
\hline
\end{tabular}

a,b,c,d means within column with an uncommon superscript are different $(\mathrm{P}<0.05)$

Endogenous urea N (EUN) and metabolic faecal N (MFN) was obtained from low nitrogen diet trial, which was $0.161 \mathrm{~W}^{0.52}(\mathrm{~g} / \mathrm{d})$ and $0.376 \mathrm{~W}^{0.52}(\mathrm{~g} / \mathrm{d})$, respectively. As dietary $\mathrm{CP}$ level increased from 6.7 to $13.4 \%, \mathrm{~N}$ retention rate (expressed as $\mathrm{N}$ retention/ $\mathrm{N}$ intake) increased from 21.1 to $28.0 \%$, and the true digestibility of $\mathrm{N}$ increased from 72.4 to $83.5 \%$ (Table 4 ).

Table 4. Effect of dietary $\mathrm{CP}$ level on daily gain, carcass weight and $\mathrm{N}$ digestibility

\begin{tabular}{lccc}
\hline \multirow{2}{*}{ Item } & \multicolumn{3}{c}{ Dietary CP level, \% } \\
\cline { 2 - 4 } & 6.7 & 10.1 & 13.4 \\
\hline $\mathrm{N}$ intake, g/d & 19.0 & 32.0 & 41.8 \\
$\mathrm{~N}$ retention, g/d & 4.0 & 7.3 & 11.7 \\
$\mathrm{~N}$ retention rate, \% & 21.1 & 22.8 & 28.0 \\
$\mathrm{~N}$ apparent digestibility, \% & 51.8 & 65.9 & 73.8 \\
$\mathrm{~N}$ true digestibility, \% & 72.4 & 78.4 & 83.5 \\
Daily gain, kg & 0.054 & 0.194 & 0.247 \\
Carcass weight, kg & 77.5 & 81.1 & 90.5 \\
BW gain/feed intake & 0.025 & 0.091 & 0.116 \\
\hline
\end{tabular}

In growing yak, digestible $\mathrm{CP}$ requirement for maintenance $\left(\mathrm{RDCP}_{\mathrm{m}}, \mathrm{g} / \mathrm{d}\right)$ determined from $\mathrm{N}$ balance trial is $6.09 \mathrm{~W}^{0.52}$, and that for gain $\left(\mathrm{RDCP}_{\mathrm{g}}\right)$ in growing yak, determined from a package of experiments including feeding trial, slaughter trial and nitrogen balance trial, can be expressed as:

$$
\mathrm{RDCP}_{\mathrm{g}}(\mathrm{g} / \mathrm{d})=\left(1.1548 / \mathrm{DG}+0.0509 \mathrm{~W}^{0.52}\right)^{-1}
$$

where DG is daily gain $(\mathrm{g} / \mathrm{d})$. 
Combining the value of $\mathrm{RDCP}_{\mathrm{m}}$ and $\mathrm{RDCP}_{\mathrm{g}}$, the $\mathrm{DCP}$ requirement (RDCP) of growing yak can be calculated as:

$$
\operatorname{RDCP}(\mathrm{g} / \mathrm{d})=6.09 \mathrm{~W}^{0.52}+\left(1.16 / \mathrm{DG}+0.05 / \mathrm{W}^{0.52}\right)^{-1}
$$

Body weight of yak grazing on native grassland showed a typical zigzag growth pattern. Supplementation in cold season aided in counteracting the BW loss of yak in cold season (Figure 1).

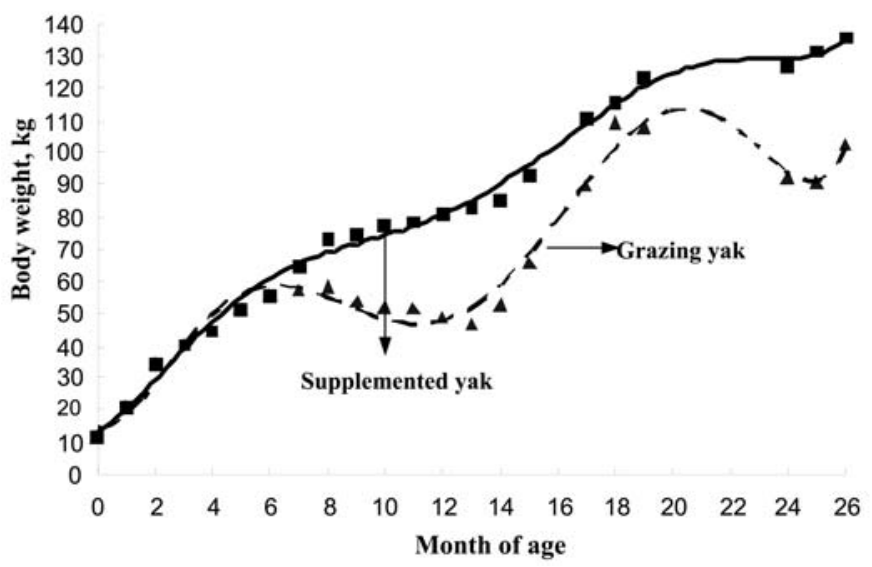

Figure 1. Growth pattern of supplemented yak and grazing yak

\section{DISCUSSION}

In most part of Qinghai-Tibet Plateau, yaks are rotationally grazed on seasonal grassland on household basis. Herders contract grassland from government and then divided it into winter-spring grassland (from the middle of Oct to the middle of the following May) which is in flat area and convenient for transportation and living, and summer-autumn grassland (from the middle of May to the middle of Oct) which is in high mountains. From Figure 1, together with digestible CP

Table 5. Gap on DCP requirement between grazing yak and supplemented yak in cold season

\begin{tabular}{lcccccc}
\hline & \multicolumn{3}{c}{ The first cold season } & \multicolumn{3}{c}{ The second cold season } \\
\cline { 2 - 7 } & grazing & supplemented & gap & grazing & supplemented & gap \\
\hline BWC, $\mathrm{kg}$ & -9.3 & 27.7 & 37.0 & -19.0 & 15.6 & 34.6 \\
DG, g/d & -43.9 & 130.7 & 174.6 & -89.6 & 73.6 & 163.2 \\
RDCP, kg & 16.218 & 30.515 & 14.297 & 19.431 & 31.819 & 12.388 \\
RDCP, g/d & 76.50 & 143.94 & 67.44 & 91.66 & 150.09 & 58.43 \\
\hline
\end{tabular}

BWC - body weight change; DG - daily gain 
(DCP) requirement, we calculated that supplemented yak required $30.515 \mathrm{~kg}$ DCP in the first cold season (6- to $13-\mathrm{mo}$ old) and $31.82 \mathrm{~kg}$ DCP in the second cold season (18- to 25-mo old) for normal growth, and grazing yak required 16.22 $\mathrm{kg}$ DCP in the first cold season and $19.43 \mathrm{~kg}$ DCP in the second cold season for adaptation to nutrient supply and environment (Table 5). Therefore, the RDCP gap between grazing yak and supplemented yak was $14.30 \mathrm{~kg}$ in the first cold season and $12.39 \mathrm{~kg}$ in the second cold season. We can conclude that grazing yak should be supplemented with $67.4 \mathrm{~g} / \mathrm{d}$ DCP in the first cold season and 58.4 $\mathrm{g} / \mathrm{d}$ DCP in the second cold season for normal growth. This conclusion could serve as the guidance of $\mathrm{CP}$ supplementation for yak grazing on winter-spring grassland in Qinghai-Tibet Plateau. Hu et al. (1999) found that yak BW loss in winter was $115 \mathrm{~g} / \mathrm{d}$ without supplementation, $20 \mathrm{~g} / \mathrm{d}$ with $110 \mathrm{~g} / \mathrm{d}$ urea-molasses block supplementation, and nil when grassland was applied with 50 to $80 \mathrm{~kg} \mathrm{~N}$ fertilizer per ha. Here we present another alternative.

\section{CONCLUSIONS}

It is concluded that there is a severe shortage of digestible crude protein supply for yak during cold season in Qinghai-Tibet Plateau, which lead to body weight loss of yak in cold season. Grazing yak should be supplemented with $67.4 \mathrm{~g} / \mathrm{d}$ DCP in the first cold season and $58.4 \mathrm{~g} / \mathrm{d}$ DCP in the second cold season for normal growth.

\section{REFERENCES}

Hu L.H., Xie A.Y., Liu S.J., Wang W.B., Xue B., Chai S.T., Han X.T., 1999. Study on nitrogen metabolism and nitrogen supplementary techniques in growing yaks. Acta Zoonutr. Sinica 11, Suppl., 208-216

Long R.J., Apori S.O., Castro F.B., Ørskov E.R., 1999. Feed value of native forages of the Tibetan Plateau of China. Anim. Feed Sci. Tech. 80, 101-113

SAS, 1993. SAS/STAT User Guide. Statistical Analysis Systems Institute Inc. Cary, NC 